\title{
REFORMASI ADMINISTRASI PELAYANAN PUBLIK (STUDI PELAYANAN ADMINISTRASI TERPADU KECAMATAN JAWA \\ TENGAH)
}

\author{
Sulistiyo Ardi Nugroho ${ }^{1}$, Kismartini ${ }^{2}$, Hartuti Purnaweni ${ }^{3}$
}

\begin{abstract}
Percepatan reformasi administrasi di daerah adalah mewujudkan tata kelola pemerintahan daerah yang baik (good localgovernance) yang terfokus pada peningkatan kualitas penyelenggaraan pelayanan publik. Didalam meningkatkan kualitas penyelenggaraan pelayanan publik diperlukan inovasi pelayanan publik. Pelayanan Administrasi Terpadu Kecamatan (PATEN) merupakan inovasi sederhana untuk melaksanakan reformasi Administrasi di tingkat daerah (local), khususnya di Kecamatan. Penelitian Reformasi Administrasi Pelayanan Publik (Studi Pelayanan Administrasi Terpadu Kecamatan di Jawa Tengah ) ini menggunakan metode penelitian kualitatif - diskriptifAnalisa data dilakukan melalui tahap reduksi data, penyajian data dan penarikan kesimpulan. Hasil penelitian Pelaksanaan Pelayanan Administrasi Terpadu Kecamatan (PATEN) di Jawa Tengah telah 0.Tengah. Dengan persyaratan PATEN yaitu syarat substantif, administratif dan teknis telah mendorong Bupati/Walikota di Jawa Tengah untuk melimpahakan kewenanganya kepada camat dan memperkuat peran dan fungsi Kecamatan. Tidak hanya sebagai Satuan Kerja Perangkat Daerah dan pelaksanana tugas pemerintahan umum, namun juga melaksanakan peran fungsi sebagai unit pelayanan terpadu di Kecamatan. Hal ini telah membuat kecamatan menjadi sangat strategis di tingkat Kabupaten/Kota, yaitu menjadi simpul pelayanan terpadu bagi Kantor/Badan Pelayanan Terpadu di Kabupaten.Dengan adanya PATEN di Jawa Tengah, membuat Kecamatan - Kecamatan di Jawa Tengah memiliki visi, misi, maklumat pelayanan, Standart Operating Procedure (SOP) sehingga tingkat akuntabilitas dan budaya kerja di Kecamatan meningkat. Hal lain yang menonjol pada umumnya dengan pelaksanaan PATEN adalah peningkatan sarana prasarana pelayanan.
\end{abstract}

Kata Kunci : Reformasi, Reformasi Administrasi, Pelayanan Publik

\section{PENDAHULUAN}

\section{Latar Belakang}

Penyelenggaraan pelayanan kepada masyarakat merupakan fungsi yang harus dilaksanakan pemerintah dalam rangka mewujudkan kesejahteraan, sebagai tolak ukur terselenggaranya tata kelola pemerintahan yang baik (good governance). Pintu masuknya bagi percepatan reformasi administrasi di daerah adalah mewujudkan tata

\footnotetext{
${ }^{1}$ Mahasiswa Magister IlmuAdministrasiPublikUniversitasDiponegoro Semarang ${ }^{2}$ DosenIlmuAdministrasiPublikUniversitasDiponegoro Semarang (PembimbingPertama)

${ }^{3}$ DosenIlmuAdministrasiPublikUniversitasDiponegoro Semarang (PembimbingKedua)
} 
kelola pemerintahan daerah yang baik (good local governance) yang terfokus pada peningkatan kualitas penyelenggaraan pelayanan publik.

Kondisi pelayanan publik di Indonesia masih jauh dari harapan masyarakat. Bebarapa survey yang dilakukan oleh beberapa lembaga juga menunjukkan rapor yang buruk pelayanan publik di Indonesia (World Bank, International Finance Corporation (IFC), Tranparency International Indonesia (TII))

Indeks Persepsi Korupsi (Corruption Perception Index/CPI) Indonesia masih rendah. Pada 2012, Transparency International mengumumkan kalau Indonesia menempati urutan ke 118 dari 176 negara dalam CPI 2012. Tahun 2013 dan 2014 skor Indonesia adalah 32 dan 34, dan sejajar posisinya dengan Republik Dominika, Ekuador, Mesir, dan Madagaskar.

Jika dibandingkan negara di kawasan Asia Tenggara, Indonesia ada di bawah Singapura (skor 87 di peringkat 5 dunia), Brunei Darussalam (skor 55 di peringkat 46 dunia), Malaysia (skor 49 di peringkat 54 dunia), Thailand (skor 37 di peringkat 88 dunia), dan Filipina (skor 34 di peringkat 118 dunia).

Kualitas penyelenggaraan pelayanan umum (publik) di daerah harus untuk ditingkat kearah yang lebih baik. Perubahan atau reformasi Administrasi pelayanan publik diarahkan pada optimalisasi penyelenggaraan pelayanan pada tingkat pelayanan yang paling dekat kepada masyarakat. Dengan terbitnya Peraturan pemerintah Nomor 19 tentang Kecamatan, Undang - Undang Nomor 25 Tahun 2009 Tentan Pelayanan Publik dan Undang - Undang Nomor 23 Tahun 2014 tentang Pemerintahan Daerah, peran kecamatan sebagai Satuan Perangkat Kerja Daerah yang dekat secara administratif, geografis maupun filosofis kepada masyarakat, memiliki peran yang semakin meningkat. Peningkatan peran itu tidak hanya pada pelaksanaan tugas dan fungsi sebagai Satuan Kerja Perangkat Daerah (SKPD) dan tugas pemerintahan umum sebagai kepanjangan tangan Gubernur Sebagai Wakil Pemerintah Pusat, namun memiliki peran dan fungsi yang baru sebagai unit pelayanan terpadu di tingkat kecamatan. Unit pelayanan ini menjadisimpul pelayanan bagi kantor/badan pelayanan terpadu di kabupaten/Kota sekaligus meningkatkan kualitas pelayanan dan mendekatkan pelayanan kepada masyarakat.

Pelayanan Administrasi Terpadu Kecamatan (PATEN) merupakan inovasi sederhana untuk melaksanakan reformasi Administrasi di tingkat daerah (local), 
khususnya di Kecamatan. Inovasi sederhana namun memberikan manfaat yang besar, selain mempermudah masyarakat memperoleh pelayanan, juga memperbaiki citra dan legitimasi pemerintah daerah di mata masyarakat.

Di Jawa Tengah, pelaksanaan reformasi Administrasi melalui pelayanan Administrasi terpadu kecamatan (PATEN) telah dilaksanakan secara bertahap mulai tahun 2011 dengan launching PATEN di Kabupaten Jepara dan secara bertahap diikuti Kabupaten/Kota se Jawa Tengah. Meskipun sampai akhir bulan desember 2015 masih ada 3 Kabupaten/Kota yang belum melaksanakan PATEN. Kabupaten/Kota tersebut adalah Kabupaten Sukoharjo, Kudus dan Kota Surakarta.

Pelaksanan Reformasi Administrasi melalui pelayanan Administrasi Terpadu Kecamatan (PATEN) di Jawa Tengah masih belum telaksana dengan maksimal, permasalahan ini terkait kedudukan dan peran Provinsi Jawa Tengah, dimana dalam Matrix of optimum reform strategy atau Matriks dari Strategi Pembaharuan Optimum yang disampaikan Hahn Been Lee, refomasi administrasi dapat dilakukan secara komprehensif apabila dukungan kepemimpinan kuat dan waktu yang tepat/menguntungkat. Sedangkan pada kenyataanya pada era desentralisasi (otonomi daerah) sesuai Undang - Undang Nomor 23 tentang Pemerintah Daerah, Kewenangan pelayanan di Kecamatan ada pada Bupati/Walikota bukan pada Gubernur.

Terkait pelaksanaan PATEN sebagi bentuk reformasi administrasi pelayanan publik, Bupati/Walikota di Jawa Tengah memiliki komitmen yang berbeda - beda, ada yang mendukung secara penuh atau kepemimpinan yang menguntukkan (mendukung), namun pada awal pelaksanaan PATEN, banyak Bupati/Walikota yang sekedar melaksanakan pelimpahan kewenangan pada camat pada tingkat normatif saja (hanya sekedar melaksakanan kebijakan Pemerintah Pusat). Gubernur sebagai pimpinan provinsi hanya memiliki kewenangan koordinatif, sedangkan pelaksanaan PATEN memerlukan persyaratan substantif, adminitratif dan teknis, dimana seluruh persyaratan tersebut ada pada kewenagan Bupati/Walikota. Maka penenulis merumuskan maslah apa startegi reformasi administrasi pelayanan publik yang diterapakan dalam pelaksanaan PATEN di Jawa Tengah.

Tujuan pembahasan ini untuk mendeskripsikan stretegi reformasi administrasi pelayanan publik pada pelaksananaan PATEN di Jawa Tengah. 


\section{PEMBAHASAN}

\section{Pelayanan Administrasi Terpadu Kecamatan (PATEN) di Jawa Tengah}

Pelaksanaan Pelayanann Administrasi Terpadu Kecamatan (PATEN) di Jawa Tengah merupakan tindaklanjut upaya reformasi administrasi yang dilaksanakan oleh Kementerian Dalam Negeri dengan menerbitkan Peraturan Menteri Dalam Negeri Nomor 4 Tahun 2010 tentang Pedoman Pelayanan Administrasi Terpadu Kecamatan (PATEN) dan Keputusan Menteri Dalam Negeri Nomor 138 - 270 Tahun 2010 tentang Petunjuk Teknis Pedoman Pelayanan Administrasi Terpadu Kecamatan (PATEN). Kebijakan reformasi administrasi yang dirumuskan oleh Kementerian Dalam Negeri ini sejalan dengan Undang - undang Nomor 23 Tahun 2014 tentang pemerintahan , Undang - undang Nomor 25 Tahun 2009 tentang Pelayanan Publik, Peraturan Presiden Indonesia tentang Grand Design Reformasi Birokrasi 2010 - 2025 dan mengatasi permasalahan - permasalahan dalam pelayanan publik.

PATEN adalah penyelenggaraan pelayaan publik di Kecamatan pada bidang perizinan dan non perizinan dengan dasar pelimpahan sebagaian kewenagan Bupati/Walikota kepada Camat dimana proses pelayanan dari permohonan sampai dengan ketahap terbitnya dokumen dalam satu tempat. Ruang lingkup dari PATEN meliputi pelayanan bidang perizinan dan pelayanan non perizinan dengan tujuan untuk meningkatakan kualitas pelayanan dan mendekatkan pelayanan kepada masyarakat. Peningkatan kualitas pelayanan initerutama terlihat dari aspek waktu dan biaya pelayanan. Melalui PATEN, warga masyarakat dapat menerima pelayanan yang lebih ceoat dan terukur dengan jelas. Sedangkan maksud penyelenggaraan PATEN adalah mewujudkan Kecamatan sebagai pusat pelayanan masyarakat dan menjadi simpul pelayanan bagi kantor/badan pelayanan terpadu di Kabupaten/Kota.

Selanjutnya, Kecamatan sebagai penyelenggara PATEN harus memenuhi persyaratan :

1) Substantif, yaitu : pendelegasian sebagai wewenang Bupati/Walikota kepada Camat dalm bidang perizinan;

2) Administratif, yaitu : standar pelayanan dan uraian tugas personil kecamatan;

3) Teknis, yaitu : saranan prasaran dan pelaksana teknis

Dalam upaya mendukung pelaksanaan PATEN, Permendagri Nomor 4 Tahun 2010 mengamanakat untuk membentuk Tim Teknis PATEN dengan dasar Keputusan Bupati/Walikota dan Pejabat Penyelenggara PATEN di Kecamatan serta mendorong 
seluruh Kecamatan ditetapkan sebagai penyelenggara PATEN selambat - lambatnya 5 (lima) tahun sejak ditetapkanya peraturan menteri ini atau pada akhir bulan desember 2014.

Pelaksanaan Pelayanan Administrasi Terpadu Kecamatan (PATEN) di Jawa Tengah telah dimulai dari bulan Oktober tahun 2010 yaitu dengan diterbitkannya Peraturan Bupati Jepara Nomor 30 Tahun 2010 tentang Pelimpahan Sebagian Urusan Yang Menjadi Kewenangan Bupati Kepada Camat Di Lingkungan Pemerintah Kabupaten Jepara dengan launching PATEN di Kabupaten Jepara pada tanggal 31 Desember 2010 dan efektif pelaksanaan pada 2 Januari 2011 pada seluruh Kecamatan di kabupaten Jepara. Selanjutnya pada Tahun 2011 launching PATEN pada Kabupaten Sragen, Tahun 2012 launching PATEN pada Kabupaten Temanggung, Tahun 2013 Launching PATEN pada Kabupaten Tegal, Semarang, Pati, Brebes, Demak, Pemalang, Wonogiri, Purworejo, Kendal dan Kota Pekalongan, Tahun 2014 launching PATEN pada Kabupaten Cilacap, Grobogan, Purbalingga, Kebumen, Blora, Wonosobo, Kalten, Banyumas, Banjarnegara, Kota Semarang dan Kota Salatiga, Tahun 2015 launching PATENpada Kabupaten Karanganyar, Batang, Magelang, Boyolali, Pekalongan, Kota Tegal dan Kota Magelang.

Berdasarkan data tersebut dari 35 Kabupaten/Kota di Jawa Tengah, 32 Kabupaten/Kota telah melaksanakan PATEN atau 91,42\% sedangkan dari 573 Kecamatan di Jawa Tengah sudah sebanyak 511 atau 89,18\% Kecamatan telah mendapatakan pelimpahan sebagian kewenanganan dari Bupati/Walikota untuk melaksanakan PATEN.

Upaya untuk mendukung reformasi administrasi pelayanan publik melalui kebijakan Pelayanan Administrasi Terpadu Kecamatan (PATEN) telah dilaksankaan oleh Pemerintah Provinsi Jawa Tengah melalui Biro Tata Pemerintahan Setda Provinsi Jawa Tengah yaitu dimulai pada Tahun 2012 dengan mengadakan Rapat Koordinasi Penyelenggaraan Pemerintahan Kecamatan Tingkat Provinsi Jawa Tengah, dimana dipesertanya adalah kepala Bagian Tata Pemerintahan Kabupaten/Kota se Jawa Tengah dengan tema pembahasan peningkatan penyelenggaraan pemerintahan kecamatan dan PATEN. Pada kesempatan rapat tersebut Pemerintah Kabupaten Jepara sebagai pionir pelaksana PATEN di Jawa Tengah diberikan kesempatan untuk bertukar informasi 
tentang kesuksesan PATEN di Kabupaten Jepara dihadapan perwakilan Kepala Bagian Pemerintahan se Jawa Tengah.

Langkah selanjutnya dalam upaya mendukung pelaksanaan reformasi administrasi pelayanan publik melalui kebijakan Pelayanan Administrasi Terpadu Kecamatan (PATEN) di Jawa Tengah adalah dengan melaksanakan monitoring dan evalusi pelaksanaan PATEN secara rutin dari tahun 2014 s/d 2016 oleh Biro Tata Pemerintahan Setda Provinsi Jawa Tengah dan rapat koordinasi optimalisasi PATEN di daerah oleh Badan Koordinasi Wilayah I, II, III Provinsi Jawa Tengah. Kemudian sejak tahun 2014 Badan Diklat Provinsi Tengah mengadakan : 1) Pendidikan dan pelatihan petugas pelaksanan PATEN pada Kecamatan; 2) Mengadakan Training of Trainer (TOT) Pelatih/Pejabat Pelaksana PATEN pada Kabupaten/Kota se Jawa Tengah. Pada tahun 2015 dan 2016 Biro Tata Pemerintah Setda Provisinsi Jawa Tengah mengadakan Bimbingan Teknis (BINTEK) PATEN kepada perwakilan Pejabat dan pelaksanan PATEN se Jawa Tengah. Tujuan diadakan pelatihan dan TOT serta BINTEK adalah untuk percepatan transfer pengetahuan ke Kabupaten/Kota agar Kabupaten/Kota mengetahui arti penting PATEN dan mampu secara mandiri melaksanakan PATEN.

Secara umumnya, pelaksanaan PATEN di Kecamatan di Jawa Tengah melayani perizinan dan non perizinan, pada bidang perizinan meliputi :

1) Izin Mendirikan Bangunan (IMB) untuk bangunan dengan kriteria : luas sampai dengan $100 \mathrm{~m} 2$, untuk tempat tinggal/hunian, tidak bertingkat, bukan untuk resort / kawasan perumahan.

2) Izin Usaha Pariwisata, gelanggang ketangkasan dan atraksi wisata;

3) Izin pemasangan reklame dengan kriteria poster/stiker/selebaran;

4) Izin Gangguan (HO) untuk usaha yang berdampak lingkungan kecil ;

5) Izin Salon Skala Kecil ;

6) Izin Rumah Makan Skala Kecil;

7) Izin Usaha perdagangan (SIUP Kecil) dan Tanda Daftar Perusahaan (TDP) dengan skala kecil.

Sedangkan kewenangan non perizinan pada legalisasi administrasi yang berdapat kecil dan membantu proses administrasi kependudukan.

Untuk menguatkan kewenangan pada reformasi administrasi pelayanan publik melalui kebijakan Pelayanan Administrasi Terpadu Kecamatan (PATEN) pada 
Tingkat Nasional, Pemerintah Pusat telah menetapkan kebijakan perizinan usaha mikro dan kecil (IUMK) dilaksankaan melalui mekanisme PATEN di Kecamatan dengan berpedoman pada:

1) Peraturan Presiden Republik Indonesia Nomor 98 Tahun 2014 Tentang Perizinan Untuk Usaha Mikro dan Kecil;

2) Peraturan Menteri Dalam Negeri Nomor 83 Tahun 2014 tentang Pedoman Pemberian Izin Usaha Mikro dan Kecil;

3) Surat Edaran Menteri Dalam Negeri Nomor 518/7485/SJ Tanggal 15 desember 2014 Tentang Pemberian Izin Usaha Mikro dan Kecil (IUMK) di Kecamatan

4) Kesepakatan tiga Menteri yaitu Menteri Dalam Negeri, Menteri Koperasi dan UMKM dan Menteri Perdagangan tentang pelaksanaan Izin Usaha Menengan dan Kecil di laksanakan di Kecamatan

Selanjutanya dalama upaya mendukung kebijakan penguatan reformasi administrasi pelayanan publik melalui kebijakan Pelayanan Administrasi Terpadu Kecamatan (PATEN) dari Pemerintah Pusat tersebut diatas, Provisi Jawa Tengah telah menerbitkan surat edaran agar Bupati/Walikota se Jawa Tengah untuk segera melimpakan pelaksananaan perizinan IUMK ke Camat dan terus medorong melalui rapat - rapat tentang Pemerintahan Kecamatan pada tingkat Provinsi. Hasilnya sudah beberapa Kabupate/Kota di Jawa Tengah melaksanakan perizinan IUMK melalui mekanisme PATEN, seperti Kabupaten Sragen, Kabupaten Boyolali, Kabupaten Temanggung, Kabupaten Magelang, Kota Tegal dan Kota Magelang.

Pada tingkat regional, khusunya pada Provinsi Jawa Tengah, penguatan reformasi administrasi pelayanan publik melalui kebijakan Pelayanan Administrasi Terpadu Kecamatan (PATEN) dilaksanakan melalui inovasi“SAMSAT PATEN" dengan percontohan pada 10 Kecamatan di Jawa Tengah. SAMSAT PATEN adalah pelayanan pembayaran pajak daerah, pembayaran sumbangan wajib dana kecelakaan lalulintas jalan dan angkutan jalan (SWDKLLAJ) dan pengesahan surat tanda nomor kendaraan bermotor melalui pelayanan Administrasi terpadu kecamatan (PATEN). Maksud dan tujuan dari SAMSAT PATEN adalah untuk mengintegrasikan pelanyanan pajak daerah dan SWDKLLAJ dengan pelayanan PATEN di Kecamatan dan meningkatkan kualitas serta mendekatkan pelayanan kepada masyarakat. 
Kecamatan yang dipilih sebagai percontohan adalah kecamatan yang secara geografir berada jauh dari pusat ibukota Kabupaten atau kecamatan yang menjadi penghubung antar kecamatan terluar antar Kabupaten. Kecamatan tersebut adalah Kecanatan Manyong di Kabupaten Jepara, Kecamatan eromoko di Kabupaten Wonogiri, Kecamatan Tanon di Kabaten Sragen, Kecamatan Larangan di Kabupaten Brebes, Kecamatan Kutoarjo di Kabupaten Purworejo, Kecamatan Bukateja di Kabupaten Purbalingga, Kecamatan Sokaraja di Kabupaten Banyumas, Kecamatan Kunduran di Kabupaten Blora, Kecamatan Wirosari di Kabupaten Grobogan dan Kecamatan Kaliori di Kabupaten Rembang.

Dalam Pelaksanaan SAMSAT PATEN rencananya akan diperluas tidak hanya pada 10 Kecamatan yang sudah ada pada saat ini, namun dapat diperluas kepada kecamatan - kecamatan yang secara geografis jauh dari ibukota Kabupaten dan menjadi penghubung antar kecamatan dan antar kabupaten. Hanya saja terdapat kendala pada ketersediaan tenaga aparatur dari tingkat Provinsi dan Kabupaten yang disebabkan moratorium penerimaan pegawai, komitmen dari Bupati/walikota yang tidak sama dalam mendukung PATEN, keterbatasan anggaran dan sarana parsarana di tingkat Kecamatan.

Selanjutnya dalam pelaksanaan reformasi administrasi melalui pelaksanaan PATEN di tingkat Kabupaten/Kota di Jawa Tengah, kondisinya beragam. Keberagaman kondisi ini karena kewenangan aplikasi secara langsung berada pada komitmen Bupati/Walikota dan perangkat birokrasi di Kabupaten/Kota untuk melakukan pelimpahan sebagaian kewenangan Bupati/Walikota kepada Camat dan bagaimana menyusun standar operating proceduredan pemenuhan sarana parasarana dan sumberdaya aparatur di Kecamatan.Di Kabupaten/Kota di Jawa Tengah terkait pemenuhan persyaratan substantif, administratif dan teknis dalam mendukung pelaksanaan PATEN juga tidak sama dalam tingkat komitmennya, ada yang mendukung dengan komitmen tinggi namun ada yang sekedar normatif saja, yaitu sekedar melaksanakan regulasi dari Pemerintah Pusat.

Kondisi keberagamanan kualitas PATEN di Jawa Tengah, sebenarnya sudah diantisipa oleh Pemerintah Provinsi Jawa Tengah melalui pelaksanaan rapat koordinasi, bimbingan teknis, pendidikan dan pelatihan, monitoring, evaluasi dan pembinaan yang dilaksanakan oleh Biro Tata Pemerintahan Setda Prov Jawa Tengah dan Badan Diklat 
Provinsi Jawa Tengah. Namun karenan sesuai amanat Undang - Undang Nomor 23 Tahun 2014 tentang Pemerintahan Daerah bahwa pelayanan publik ditingkat kecamatan menjadi kewenangan Bupati/Walikota, Pemerintah Provinsi pada saat ini hanya memiliki kapasitas untuk melakukan dorongan melalui pembinaan, pelatihan dan koordinasi belum memiliki kewenangan untuk melakukan reward dan punisment.

Tanpa mempersoalkan pemasalahan kewenangan yang ada lebih lanjut, Pemerintah Provinsi Jawa Tengan melalui unsur SKPDnya terus melakukan upaya mendukung reformasi administrasi melalaui PATEN di Jawa Tengah, dengan hasil 32 kabupaten/Kota telah melaksanakan PATEN dan 511 Kecamatan telah mendapatkan pelimpahan kewenangan dari Bupati/Walikota untuk melaksanakan PATEN. Secara umum dengan adanya PATEN, telah terjadi :

1) Perubahan pelaksanaan pengurusan permohonan perizinan dan non perizinan skala kecil dari Badan/Kantor Pelayanan Perizinan Terpadu di ibukota Kabupaten ke Kecamatan, sehingga mendekatkan pelayanan bagi masyarakat di tingkat Kecamatan.

2) Adanya rintisan untuk memperluasaksesmasyarakatuntukmengaksesinformasi, menilaidanmembermasukan agar terciptapelayanan yang berkualitas

3) Memperkuatkepercayaanmasyarakatkepadapemerintahkecamatandanmeningkatka nkesadaranwargabahwapelayananpublicyangberkualitasbukanhanyatanggungjawa bpemerintah, tetapijugawargapenggunalayanan

4) Lebihmemberikeadilankepadasemuastaf, sehinggatidakadalagiistilahbagian yang "basah" dan "kering"

5) Dukungan alokasi anggaran bagi Kecamatan untuk perbaikan sarana dan prasarana pelayanan, seperti loket pelayanan, ruang pelayanan, ruang tunggu, pendingin ruangan dan sarana teknologi inforamasi (IT)

Praktek PATEN yang baik di Jawa Tengah, sebagai contoh dapat ditemukan antara lain pada:

1) Kecamatan Baturraden di Kabupaten Banjarnegara, dengan inovasi pelayanan perizinan dan non perizinan dengan standar ruang pelayanan dan sumber daya aparatur serta Standart Operating Procedure (SOP) yang baik sepertipelayanan di swasta, sarana prasaran pelayanan yang telah berpihak kepada masyarakat yang 
berkebutuhan khususdengan di dukung pelayanan administrasi yang baik di tingkat Kelurahan dan Desa.

2) Kecamatan Prambanan di Kabupaten Klaten, dengan inovasi ruang pelayanan PATEN yang modern, nyaman, sarana prasaran pelayanan yang telah berpihak kepada masyarakat yang berkebutuhan khusus serta adanya Standart Operating Procedure (SOP) yang baik yangdi dukung teknologi informasi

3) Kecamatan Karanggede, Ampel dan Nogosari di Kabupaten Boyolali, dengan inovasi ruang pelayanan PATEN yang modern, nyaman dan serta adanya Standart Operating Procedure (SOP) yang baik (seperti di perbankan) serta adanya Sistem IT berupa Sistem Informasi Kecamatan Terpadu (SIMANTAP) yang telah diintegrasikan dengan Aplikasi E-Office.

4) KecamatanWonosobo, Selomerto, Kalikajar, dan Wadaslintang di Kabupaten Wonosobo dengan inovasi ruang pelayanan PATEN yang modern dan nyaman (seperti di perbankan) dan pelayanan perizinanan non perizinan yang terintegrasi melaalui tool aplikasi Sistem Informasi Terintegarasi(SINTA) serta proses pelayanan dimulai dari admin (perangkat) desa/kelurahan.

5) Seluruh Kecamatan di Kabupaten Sragen dengan inovasi ruang pelayanan PATEN yang modern, nyaman, adanya Standart Operating Procedure (SOP) yang baik dan dukungan teknologi informasi di ruang pelayanan serta integrasi pelaksanaan pelayanan PATEN dari tingkat Desa/Kelurahan yang disebut Pelayanan Administrasi Terpadu Desa (PADMA).

\section{Strategi Reformasi Administrasi PATEN di Jawa Tengah}

Strategi reformasi administrasi pelayanan publik pada pelaksanaan PATEN di Jawa Tengah sesuai Matriks Strategi Pembaharuan Optimum yang disampaikan oleh Han Been Lee secara umum pada tingkat provinsi pada dimensi kepemimpinan yang tidak menguntungkan/lemah dan waktu yang menguntungkan atau Kepemimpinan yang menguntungkan/kuat dan waktu yang menguntungkan sehingga alternatif starteginya adalah inkremental dan pendekatan mikro (selektif).

Kondisi ini ditunjukan dengan komitmen yang kuat dari Gubernur Jawa Tengah melalui peranngkat SKPDnya dalam mendukung reformasi administrasi pelayanan publik melalaui PATEN namun terdapat perbedaan tingkat komitmen Bupati/Walikota dalam melaksanankan PATEN, baik dalam pemenuhan syarat 
substantif, adminitratif dan teknis. Mengenai dimensi waktu, secara umum dalam waktu yang menguntungkan dengan bersamaan diterbitkanya Peraturan Pemerintah Nomor 19 Tentang Kecamatan, Undang - undang Nomor 23 Tahun 2014 tentang pemerintahan , Undang - undang Nomor 25 Tahun 2009 tentang Pelayanan Publik, Peraturan Presiden Indonesia tentang Grand Design Reformasi Birokrasi 2010 - 2025.

Strategi yang selektif atau pendekatan mikro ini dilakukan dengan mendorong kabupaten/Kota yang memiliki komitmen yang kuat dalam pelaksanaan PATEN, kemudian dijadikan contoh sukses dalam rapat koordinasi dan monitoring PATEN untuk mendorong percepatan pelaksanaan PATEN di kabupate/kota lain di Jawa Tengah. Dengan hasil, yang mulanya 3 kabupaten/kota yang melaksanakan PATEN di tahun 2012, pada akhir bulan Desember 2015 sudah sebanyak 32 Kabupaten di Jawa Tengah melaksanakan PATEN atau 91,42\%. Pada tingkat Kecamatan 573 Kecamatan di Jawa Tengah sudah sebanyak 511 atau 89,18\% Kecamatan telah mendapatakan pelimpahan sebagian kewenanganan dari Bupati/Walikota untuk melaksanakan PATEN.

Bentuk stategi selektif/pendekatn mikro dilakukan pada tahun 2012 dengan mengundang Sekretaris Daerah kabupaten Jepara menjadi pembicara inspiratf tentang PATEN pada Rapat Koordinasi Kecamatan Tingkat Provinsi Jawa Tengah, dimana pesertanya adalah Kepala Bagian Pemerintahan se Jawa Tengah. Pada tahun 2013, 2014 dan 2015 dilakukan dengan menyampaikan hasil monitoring pelaksanaan PATEN pada setiap rapat tingkat Provinsi pada bidang pemerintahan Kecamatan yang diampu oleh Biro Tata Pemerintahan Setda Provinsi Jawa Tengah dan Badan Koordinasi Wilayah I, II dan III Provinsi Jawa Tengah. Selanjutnya pada tahun 2016 dengan mengundang Camat Baturraden Kabupaten Banyumas untuk menjadi pembicara inspiratif pada Bimbingan Teknis PATEN tingkat Provinsi Jawa Tengah dengan SKPD pengampu Biro Tata Pemerintahan Setda Provinsi Jawa Tengah.

Stategi yang selektif dan pendekatan mikro yang dilakukan pemerintah Provinsi Jawa Tengah yang lain, antara lain dilakukan Badan Diklat Provinsi Jawa Tengah melalui pelatihan petugas pelaksanan PATEN di tingkat Kecamatan, pelaksanaan Training of Trainer (TOT) Pelatih/Pejabat Pelaksana PATEN pada Kabupaten/Kota se Jawa Tengah. Oleh Dinas Pendapatan dan Pengelolaan Aset Daerah Provinsi Jawa Tengah dukungan reformasi administrasi pelayanan publik melalaui PATEN dilakukan melalui inovasi "SAMSAT PATEN" dengan tujuan membuat 
msyarakat merasakan manfaat keanekaragaman kemudahan pelayanan pada pelaksanaan pelayanan publik melalui mekanisme PATEN.

Pelaksanaan PATEN di Jawa Tengah sebagai bentuk startegi reforamasi administrasi publik di daerah memberikan manfaatpada :

1) Kelembagaan :

a) Adanya pendelegasian sebagaian kewenangan dari Bupati/Walikota kepada Camat sebagai persyaratan substantif PATEN. Halini memberikan dampak peningkatan peran dan fungsi camat, dengan peningkatan peran fungsi camat tentunya memberikan dampak ikutan meningkatan peran dan fungsi aparatur di kecamatan.

b) Adanya perubahan peran dan fungsi Kecamatan, yang pada awalnya sebagai Satuan Kerja Perangkat Daerah dan pelaksanan tugas pemerintahan umum, bertambah menjadi unit pelayanan publik. Dengan adanya penambahan peran dan fungsi Kecamatan di Jawa Tengah tentunya memberikan konsekuanesi adanya perubahan budaya kerja, yang tadinya hanya sebagai koordinator pemerintahan di kecamatan menjadi aparatur yang melayani publik.

2) Ketatalaksanaan :

a) Pelaksanaan PATEN di Jawa Tengah memberikan manfaat bagi Kecamatan untuk membuat dan menetapakan standart operating prosecedur (SOP) dalam pelayanan di Kecamatan. Dengan penetapan SOP tentunya telah terjadi reformasi ketatalaksanaan di Kecamatan - kecamatan di Jawa Tengah.

b) Dengan adanya SOP memberikan manfaat kepada petugas layanan mengenai biaya, waktu dan kelengkapan administrasi yang harus dicukupi dalam permohonan pelayanan perizinan. Untuk masyarakat memberikan kejelasan kepada masyarakat tentang biaya, waktu dan prosedur. Dengan demikian potensi terjadinya penyakit birokrasi dalam pelayanan publik dapat dihindarkan.

3) Sumber daya manusia :

a) Peningkatan kualitas sumberdaya aparatur kecamatan dalam pelayanan publik, khusunya pada bidang perizinan dan non perizinan.

b) Perubahan budaya kerja dari apaartur di kecamatan, yang tadinya sebagai aparatur yang memiliki fungsi koordinatif pemerintahan desa dan kelurahan, menjadi aparatur yang harus mampu melayani masyarakat dalam pelayanan publik. 


\section{Kendala dalam Pelaksanaan PATEN di Jawa Tengah}

a) Komitmen Bupati/walikota dalam pelimpahan kewenangan kepada camat masih bersifat normatif, atau hanya sekedar melaksanakan kebijakan Pemerintah Pusat.

b) Pendanaan atau anggaran untuk pelaksanaan PATEN yang masih terbatas.

c) Sarana dan Prasaran di Kecamata yang terbatas.

d) Sumberdaya manusia apaartur di kecamatan yang terbatas, baik dari segi jumlah ataupun kapasitanya dalam peran sebagai pelayan publik.

\section{PENUTUP}

\section{Kesimpulan}

Pelaksanaan Pelayanan Administrasi Terpadu Kecamatan (PATEN) di Jawa Tengahtelah menjadi triger atau pendorong dalam reformasi adaministrasi pelayanan publik di Jawa Tengah. Dengan persyaratan PATEN yaitu syarat substantif, administratif dan teknis telah mendorong BupatiWalikota di Jawa Tengah untuk melimpahkan kewenanganya kepada camat dan memperkuat peran dan fungsi Kecamatan. Tidak hanya sebagai Satuan Kerja Perangkat Daerah dan pelaksanana tugas pemerintahan umum, namaun juga melaksanakan peran fungsi sebagai unit pelayanan terpadu di Kecamatan. Hal ini telah membuat kecamatan menjadi sangat strategis di tingkat Kabupaten/Kota, yaitu menjadi simpul pelayanan terpadu bagi Kantor/Badan Pelayanan Terpadu di Kabupaten.

Dengan adanya PATEN di Jawa Tengah, membuat Kecamatan - Kecamatan di Jawa Tengah memiliki visi, misi, maklumat pelayanan, Standart Operating Procedure (SOP) sehingga tingkat akuntabilitas dan budaya kerja di Kecamatan Meningkat. Hal lain yang menonjol pada umumnya dengan pelaksanaan PATEN adalah peningkatan sarana prasarana pelayanan dalam bentuk ruang pelayanan yang nyama dengan adanya fasilitas loket pelayanan yang baik, ruang tunggu yang nyaman, pendingin ruangaan dan sarana parasarana yang berpihak pada masyarakat yang berkebutuhan khusus.

Pada akhirnya PATEN di Jawa Tengah, meskipun masih harus terus ditingkatkan pada tingkat komitmen kepala daerah baik pada Tingkat Provinsi, Kabupaten dan Kota telah memberikan perbaikan pada reformasi administrasi pelayanan publik pada sisi kelembagaan, tatalaksana dan sumberdaya manusia pada tingkat Kecamatan di Jawa Tengah 


\section{DAFTAR PUSTAKA}

\section{Sumber Buku :}

Bungin, Burhan, 2007, Penelitian Kualitatif Komunikasi, Ekonomi, Kebijakan Publik, dan Sosial Lainnya, Edisi Kedua, Kencana Prenanda Media Group, Jakarta.

Dunn, William N, 2003, Pengantar Analisa Kebijakan Publik, Edisi Kedua, Gadjah Mada University Press, Yogyakarta

Farazmand, Ali \& Mittner Frederick, 2004, Total Quality Management in Public Management: An Innovation Strategy for Managerial Capacity Building, Westport Connecticut, London.

Hardiyansyah, 2011, Kualitas Pelayanan Publik, Konsep, Dimensi, Indikator dan Implementasinya, Cetakan I, Gava Media, Yogyakarta.

Mulyadi, Deddy, 2015, Studi Kebijakan Publik dan Pelayanan Publik, Konsep dan Aplikasi Proses Kebijakan Publik dan Pelayanan Publik, Cetakan Kesatu, Alfabeta, Bandung.

Nugroho, Riant, 2013, Metode Penelitian Kebijakan,Pustaka Pelajar, Yogyakarta.

Parsons, Wayne,2011, Public Policy Pengantar Teori dan Praktik Analisa Kebijakan, Kencana Prenanda Media Group, Jakarta.

Purwanto, Erwan Agus, dkk, 2015, Implementasi Kebijakan Publik, Konsep dan Aplikasi di Indonesia, Cetakan Kedua, Gava Media, Yogyakarta

Pasolong, Harbani, 2014, Teori Administrasi Publik, Cetakan Keenam, CV. Alfabeta, Bandung

Thamrin, Husni, 2013, Hukum Pelayanan Publik Indonesia, Cetakan II, Aswaja Pressindo, Yogyakarta.

Sedarmayanti, 2013, Reformasi Administrasi Publik, Reformasi Birokrasi, dan Kepemimpinan Masa Depan (Mewujudkan Pelayanan Prima dan Kepemerintahan Yang Baik), Cetakan Ketiga, PT. Refika Aditama, Bandung

Sugiyono, 2013, Metode Penelitian Manajeman, Alfabeta, Bandung

Wahab, 2015, Solichin Abdul, Analisis Kebijakan, Dari Formulasi ke Penyusunan Model - Model Implementasi Kebijakan, Cetakan Ketiga, PT. Bumi Aksara, Jakarta

Zauhar, Soesilo, 2002, Reformasi Administrasi Konsep, Dimensi dan Startegi, Cetakan Kedua, PT. Bumi Aksara, Jakarta 
Flassy, dkk, 2010, Jurnal : Reformasi Administrasi Publik Untuk Membangun Daya Saing Daerah : Kajian Perspektif Recource Based, Jurnal STIE Pengembangan Bisni dan Managenen, Vol X, No. 16

Hendraydy, Agus, 2011, Jurnal : reformasi Administrsai Publik, Jurnal Fisip UMRAH, Vol I, No1

Larasati, Endang : Reformasi Pelayanan Publik (Public Service Reforrm) dan Partisipasi Publik

Nasirin, Chairun, 2013, Jurnal : Reformasi Administrasi Publik : Sebuah Kajian Konseptual, Jurnal Ilmiah Administrasi Publik dan Pembangunan, Vol 4, No. 2

Puspitasari, Dian, dkk, Jurnal : Reformasi Administrasi Pelayanan Publik Pada Kantor Pelayanan Terpadu (Studi pada Disperindag dan Dispendukcapil Kota Malang), Jurnal Administrasi Publik (JAP) Vol 2, No 2

\section{Non Buku :}

2010, Kebijakan Pelayanan Administrasi Terpadu Kecamatan (PATEN), Direktorat Jenderal Pemerintahan Umum Kementerian Dalam Negeri Republik Indonesia, Jakarta.

2008, Panduan Pelayanan Administrasi Terpadu Kecamatan, Direktorat Jenderal Pemerintahan Umum Kementerian Dalam Negeri Republik Indonesia, Jakarta.

Undang - Undang Nomor 25 Tahun 2009 Tentang Pelayanan Publik.

Undang - Undang Nomor 23 Tahun 2014 Tentang Pemerintahan Daerah.

Peraturan Menteri Dalam Negeri Nomor 4 Tahun 2010 tentang Pedoman Pelayanan Adminstrasi Terpadu Kecamatan .

Peraturan Bupati Jepara Nomor 30 tahun 2010 tentang pelimpahan Sebagian Urusan Yang menjadi Kewenangan Bupati Kepada Camat Di Lingkungan Pemerintahan Kabupaten Jepara, Yang Diubah Terakhir Dengan Peraturan Bupati Jepara Nomor 17 Tahun 2011.

2014. Indeks Persepsi Korupsi Indonesia, www.ti.or.id/index.php/survey-publik dan www.transparency.org 